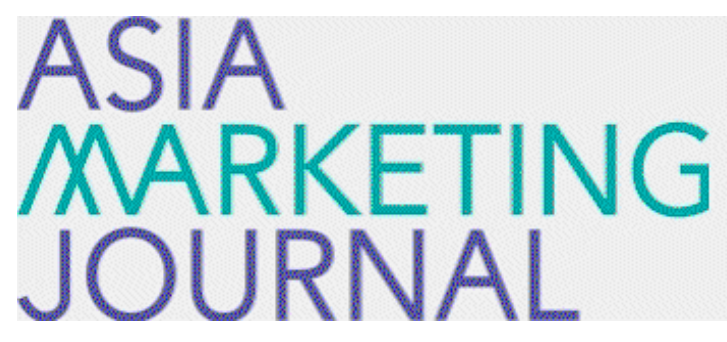

ASIA MARKETING JOURNAL

Volume 16 | Issue 1

Article 7

4-30-2014

\title{
Facebook Users in United Arab Emirates
}

Somkiat Mansumitrchai

Choo Hui Park

Candy Lim Chiu

Follow this and additional works at: https://amj.kma.re.kr/journal

Part of the Marketing Commons

\section{Recommended Citation}

Mansumitrchai, Somkiat; Park, Choo Hui; and Chiu, Candy Lim (2014) "Facebook Users in United Arab Emirates," Asia Marketing Journal: Vol. 16 : Iss. 1 , Article 7.

Available at: https://doi.org/10.53728/2765-6500.1530

This Article is brought to you for free and open access by Asia Marketing Journal. It has been accepted for inclusion in Asia Marketing Journal by an authorized editor of Asia Marketing Journal. 


\title{
Facebook Users in United Arab Emirates: Underlying the Factors and Demographic Analysis
}

\author{
Somkiat Mansumitrchai* \\ Choo-Hui Park** \\ Candy Lim Chiu***
}

This study examined the use of Facebook in United Arab Emirates. There were two objectives of this study. The first purpose was to identify the motive for the use of Facebook among people in U.A.E. This study conducted the survey using both qualitative and quantitative methods. One hundred eighty-three working people were used from the survey. Thirty-five questions identified from the interviews were used for the questionnaire design in quantitative method. Factor analysis showed six factors namely usefulness, usage, reliability, making new friends, ethical issue and openness of information. The total variance explained by all the factors was fifty-two percent.

This study also examined the demographic variables whether they would play an important role in using the social network site. The study included two more variables, income and married status, which were not frequently examined by previous studies. MANOVA showed statistical significant differences $(\mathrm{p}<.01)$ across six factors. ANOVA results showed that gender variable affected only the factor of openness of information. Males were more likely to share their information compared to females. Income variable affected all the factors except the openness of information. The results showed that high-income people had the highest meanscores on three factors (usage, reliability, making new friends) while low-income people had the highest means on usefulness and ethical factors.Marital status had significant effects on usefulness, reliability, and ethical factors. Married people had the low scores on reliability and ethical factors. Lastly, education variable had no effect on all the factors examined.

Key words: social network, facebook, factor analysis, U.A.E.

\footnotetext{
* Faculty of Marketing and Business, ALHOSN University, Abu Dhabi, United Arab Emirate

** Faculty of International Business, Keimyung Adams College, Keimyung University(shineforeverjp@gmail.com), Corresponding author

*** Independent Researcher
} 


\section{Introduction}

The number of Internet users has been increased to 2.1 billion people worldwide according to the world-fact book. Social networking sites such as Facebook have benefited from the increased with the number of online communities. Facebook became a pioneer phenomenon on the web, allowing millions of users to interact and connect in the Internet society. There were 1.23 billion people using Facebook at the end of 2013, which is 170 million increased from previous year. According to Facebook, 757 million people log on to Facebook daily, as of 31 December 2013. Facebook has changed the way people communicate, and the website has gained an increased popular awareness dramatically.

The number of people around the world using the social network site (SNS) such as Facebook has been increasing dramatically every year. Recently, the number of the Facebook users is around 1,300 million people worldwide. The U.S.A., India, Brazil and Indonesia are ranked the highest of the number of users.In U.A.E., the number of Facebook users in February 2012 was approximately 2 millions, which was accounted for $40 \%$ of the population (http://www.ameinfo.com/290591.html).

\section{The Motive of Using Social Network Site (SNS)}

The motive of using the social network was examined by many previous studies. People used the social network for their benefits, which were the reasons that motivate them to activate the websites. Usage of social network was a form of benefit found in many previous studies (Barkhuus \& Tashiro, 2010; Cheung, Chui, \& Lee, 2011). Making friends, connecting to people communicate with friends, and sharing photos and videos were among common benefitsfound in many studies (Donath\& Boyd, 2004; Lenhart \& Madden, 2007; Sheldon, 2008). In addition, social networks serve a number of functions in offline life such as providing social and emotional support (Joinson, 2008). In addition, online social networking sites also provide a number of other purposes such as social searching and social browsing (Donath \& Boyd, 2004). One study found that innovation characteristics (relative advantage, compatibility, and complexity) and perceived popularity differed significance among adopter categories (Lin, Chiu, \& Lim, 2011). Their study showed that the adoption of SNSs was positively related to perceiving relative advantage, compatibility, and complexity.

There is also a negative side for using the SNS. Issues concerned about the use of SNS were social factors. These factors included the 
gains and harms from the use of SNS (Stafford, 2006), the role in identity structure (Boyd, 2008), and the privacy concerns (Gross \& Acquisi, 2005; Hodge, 2006). Previous study found that using a social network may harm the relationship between friends and family. Safety and reliability of the site were always important issues when people decided to use the sites. Many studies showed that people were reluctant to use SNS because of the trust and privacy concern.

\section{The Effect of Demographic Variables on the Use of SNS}

Many studies found that demographic and socioeconomic are also the factors affecting the use of social network. A number of studies showed that demographic such as a gender affected the use of SNS (Bimber, 2000; Jackson, Ervin, Gardner, \& Schmitt, 2001; Ono \& Zavodny, 2003; Hargittai \& Shafer, 2006; DiMaggio, Hargittai, Celeste, \& Shafer, 2004; Livingstone \& Helsper, 2007; Mossberger, Tolbert, \& Stansbury, 2003; Van Dijk, 2005). Age and socioecomic status were found significant factors as well (Lin, Chiu, \& Lim, 2011; Howard, Rainie, \& Jones, 2001; Madden \& Rainie, 2003; Livingstone \& Helsper, 2007). Investigating two variables, age and gender, Hargittai (2008) found that gender, not age, affected the aggregate SNS usage. Mansumitrchai,
Park \& Chiu (2012) found that Korean males and females were different when they adopted SNS. Their study also indicated that age was also a factor that affected the attributes of SNS adoption. Studying a diverse group of young adults, Hargittai (2008) examined the relationship between a demographic and the use of SNS, the study found that there was an association between the use of SNS and a person's gender, race, ethnicity, and parental educational background. However, Lin, Chiu \& Lim (2011) studied the social network and found that there was no significant difference between website's users and non-users in terms of their education level and innovativeness of the respondents.

An evidence found in previous studies indicated gender differences in preferences for specific Internet applications. The results showed that women used the Internet primarily for interpersonal communication and education assistance, while men used it for entertainment and leisure. Many previous studies explored the effects of gender with social network use, and they found that men and women were different in their usage motivations. A study found that women were more likely to use e-mail, on the other hands; men were more probable to use the search on the websites (Jackson, 2001).

Whether information disclosure will be the same regarding to gender difference; previous studies showed that there were some differences. Tufekci (2008) found that men provided more 
their private information compared to women. The similar finding was evidenced in a previous study, which indicated that female students disclosed their confidential information across several areas such as photo albums and number of photographs compared to male students. An earlier study also showed that women preferred to keep their personal information only for their relatives and friends than men did (Mansumitrchai, Park and Chiu 2012).

Privacy was considered an important issue in SNS adoption (e.g. Gross \&Acquisti, 2005; Hodge, 2006). Many previous studies examined gender differences regarding to online privacy concerns. Some studies found that women were more concerned than men over the privacy issue; they were concerned that their private information might be used by others. In addition, women were more likely to give incomplete information to websites

Other demographic variables such as age, race and parental education were examined from previous studies. A study (Sheldon, 2012) found that age was considered one of the predictors of communication and social behavior for sensation seeking particular for experience seeking, disinhibition and boredom susceptibility. One study examined how the age of users on SNS correlated to the number of friends they have on the site. The result shows that age was not a significant variable for predicting the number of friends among SNS users. Hargittai (2008) found that in general a person's gender, race and ethnicity, and parental education background were all associated with the use of SNS.

The United Arab Emirates (U.A.E.) is considered one of the most advance countries in the world in terms of its technology, facilities and infrastructure. By the time of this study, there were not many studies about social network in U.A.E., giving an opportunity to explore the knowledge about the motives of the social network users in the country. This paper was intended to identify the motives of social network users in U.A.E. Among social network websites, Facebook was the second most popular among people in U.A.E., so it was used for the unit of this study. In additional, the paper examined whether the demographic variables would play an important role in using the social network.

Because there were not many studies about the motive of the SNS users in U.A.E., finding out the motive of using the SNS among people in this country was an important for research. Whether the motives of the people in U.A.E. would be the same as those of the people elsewhere was an interesting to know and explore. This issue will be examined with two primary research questions.

RQ1: What are the motives for using the SNS in U.A.E.?

RQ2: Do demographic variables play an important role in using SNS? 


\section{Research Methods}

\subsection{Research Design}

Qualitative and quantitative methods were used for the study. Qualitative method helped to identify possible motives of using Facebook among users. The results from the survey in qualitative method then were used for the questionnaire design for the next stage.

\subsection{Qualitative and Quantitative Method}

A non-probability method was used, thus the survey was conducted on the convenience of the sample. The purpose of the interviews was to explore the perception and the motive of the use of Facebook among Emirate people and also to identify possible latent variables that were applicable for U.A.E. environment.

The results from the qualitative stage were thoroughly examined and the redundancy of the results was removed.The final thirty-five questions were used for the quantitative analysis. Four-hundred questionnaires were sent to the working people who were currently using the social network sites. Three hundred people responded the questionnaire, which accounted for 87.50 per cent. From three-hundred fifty samples, the number of people who used Facebook was only 183, which was used for the next step for analysis.

\subsection{Scale Measurement}

Likert scale was used in the perception toward using Facebook for thirty-five questions. The scale ranged from 1 (strongly disagree) and 5 (strongly agree). Demographic questions and Internet uses were asked at the first section of the survey. Cronback's alpha for testing reliability and consistency of the measurements was .92 for all thirty-five items, suggesting that the measurements for the survey were reliable. The Hotelling's T-square showed significance with calculated F 10.156 at .01 level. The Barlett's Test of Sphericity was significant at .01 level, indicating that there was nonzero correlations. To measure the sampling adequacy (MSA), Kaiser-Meyer-Olkin Measure of Sampling Adequacy was significant with an MSA value of .887 . Thus, the measurements met the requirement for the factor analysis.

\section{Respondents' Demographic}

Above ninety percent of the respondents were working people in Abu Dhabi city. The survey was collected from both offices and a university. From the survey, one-hundred eighty three were identified as Facebook users, which accounted for 52.3 per cent from the respondents. There were 100 males respondents (54.6\%) and 83 females (45.4\%), and forty-one percent 
〈Table 1〉 Profile of respondents and their uses of social network

\begin{tabular}{|c|c|c|}
\hline \multirow{2}{*}{\multicolumn{3}{|c|}{ 1. Gender }} \\
\hline & & \\
\hline Male & 100 & 54.6 \\
\hline Female & 83 & 45.4 \\
\hline \multicolumn{3}{|l|}{ Missing } \\
\hline Total & 183 & 100.0 \\
\hline \multicolumn{3}{|l|}{ 2. Age } \\
\hline $20-25$ & 10 & 5.5 \\
\hline $26-30$ & 79 & 43.2 \\
\hline $31-35$ & 51 & 27.9 \\
\hline $36-40$ & 16 & 8.7 \\
\hline Above 40 & 15 & 8.2 \\
\hline Missing & 12 & 6.6 \\
\hline Total & 183 & 100.0 \\
\hline \multicolumn{3}{|l|}{ 3. Education } \\
\hline High school & 54 & 29.5 \\
\hline College degree & 110 & 60.1 \\
\hline Master degree & 19 & 10.4 \\
\hline Total & 183 & 100.0 \\
\hline \multicolumn{3}{|l|}{ 4. Income per month (in Durham) } \\
\hline Below 10,000 & 60 & 32.8 \\
\hline $10,000-30,000$ & 76 & 41.5 \\
\hline Above 30,000 & 47 & 25.7 \\
\hline Total & 183 & 100.0 \\
\hline \multicolumn{3}{|l|}{ 5. Marital Status } \\
\hline Married & 75 & 40.9 \\
\hline Not Married & 107 & 58.5 \\
\hline Missing & 1 & .5 \\
\hline Total & 183 & 100.0 \\
\hline \multicolumn{3}{|l|}{ 6. Internet access } \\
\hline Home & 39 & 21.3 \\
\hline Office & 12 & 6.6 \\
\hline Both from home and office & 104 & 56.8 \\
\hline Other & 28 & 15.3 \\
\hline Total & 183 & 100.0 \\
\hline \multicolumn{3}{|c|}{ 7. Number of months for using internet } \\
\hline Less than 6 months & 3 & 1.6 \\
\hline $6-12$ months & 10 & 5.5 \\
\hline $1-3$ years & 12 & 6.6 \\
\hline $4-6$ years & 42 & 23.0 \\
\hline 7 years or more & 115 & 62.8 \\
\hline Missing & 1 & .5 \\
\hline Total & 183 & 100.0 \\
\hline \multicolumn{3}{|c|}{ 8. Number of hours a week for using internet } \\
\hline Less than 1hour & 8 & 4.4 \\
\hline $1-5$ hours & 50 & 27.3 \\
\hline 6-10 hours & 43 & 23.5 \\
\hline 11-20 hours & 29 & 15.8 \\
\hline $21-40$ hours & 24 & 13.1 \\
\hline Over 40 hours & 29 & 15.8 \\
\hline Total & 183 & 100.0 \\
\hline
\end{tabular}


were married people. The majority of the respondents were between 26-35 years old $(n=$ 130, 72\%). Sixty percent of the participants were studying a bachelor'sdegree. Forty-two percent of the participants were considered a middle-income class in U.A.E, and twenty-five were high-income people. Table 1 summarized the demographic data of the respondents.

\section{Results}

\subsection{Factor Analysis}

To identify the factors, factor analysis with varimax rotation was tested. The cut-off point .60 was used to detect the items for each factor (see Hair, 1998). The initial test provided nine factors with the eigen value more than 1 and it explained $67.43 \%$ of total variance. However, after examining the corrected items to total correlation for each item in all nine factors, some items in factors 7, 8 and 9 were below .30 . Thus, the last three factors were dropped out from the result. Only six factors then were used for the next step. The whole variance explained by all sixvfactors was 52.84 per cent. The first factor explained 15.03 per cent of entire variance, and the second factor contributed 8.7 per cent of the total variance.

\subsection{Naming the Factor}

The names of the factors were labeled after considering the items for each factor. Six factors were named as usefulness, usage, reliability, making new friends, ethic, and openness of information. The first factor, usefulness, consisted of five items with eigen value 11.33, which accounted for 15.03 per cent of total variance. The second factor, usage, was loaded with three items with eigenvalue 2.798 (8.7 percent of variance). The third factor, reliability, contained three items with eigenvalue 1.922 (8.11 percent of variance). The fourth factor namely making new friends included two items with the eigen value 1.544 (7.51 per cent of variance). The fifth factor, ethic, consisted of two items with the eigen value 1.374 (6.801 per cent of variance). The last factor, openness of information, contained two items with the eigen value 1.26 (6.68 per cent of variance). Table 2 summarized all the results.

\subsection{MANOVA Result}

MANOVA was performed whether the demographic variables, gender, income, marital status, and education, affected the perceptions toward all the factors (usefulness, usage, reliability, making new friends, ethic, and openness of information). The results showed statistical significances for all the tests, Pillai's Trace, Wilk's Lambda, Hotelling's Trace, and 
〈Table 2〉 Results of Factor Analysis

\begin{tabular}{|c|c|c|c|c|}
\hline Factor & Mean & Std. & $\begin{array}{l}\% \\
\text { Variance }\end{array}$ & $\begin{array}{l}\text { Cummulative } \\
\% \text { Variance }\end{array}$ \\
\hline $\begin{array}{l}\text { Factor 1: Usefulness (Cronbach alpha }=.824 \text { ) } \\
\text { 1. I have time to use Facebook (.69) } \\
\text { 2. Facebook is user friendly (more convenient) } \\
\text { than other form of social network. (.65) } \\
\text { 3. Facebook is part of my everyday activity. (.63) } \\
\text { 4. Facebook lets you connect with you family, } \\
\text { friends and relatives (.64) } \\
\text { 5. There's benefit using Facebook. (.66) }\end{array}$ & 3.53 & .77 & 15.03 & 15.03 \\
\hline $\begin{array}{l}\text { Factor 2: Usage (Cronback alpha }=.868 \text { ) } \\
\text { 1. I like sharing photos. (.83) } \\
\text { 2. I like sharing videos. (.83) } \\
\text { 3. I like downloading photos and videos in Facebook.(.72) }\end{array}$ & 3.13 & 1.03 & 8.70 & 23.70 \\
\hline $\begin{array}{l}\text { Factor 3: Reliability (Cronback alpha }=.752) \\
\text { 1. Information shared in Facebook is reliable. (.63) } \\
\text { 2. There's privacy in Facebook. (.79) } \\
\text { 3. Using Facebook is safe and secured. (.83) }\end{array}$ & 2.84 & .96 & 8.11 & 31.84 \\
\hline $\begin{array}{l}\text { Factor 4: Making New Friends (Cronbach alpha }=.742 \text { ) } \\
\text { 1. Meeting new friends in Facebook is } \\
\text { good way to socialize. (.60) } \\
\text { 2. It's interesting to make friends from other countries. }(.71)\end{array}$ & 3.48 & .84 & 7.51 & 39.35 \\
\hline $\begin{array}{l}\text { Factor } 5 \text { : Ethic (Cronbach alpha }=.732 \text { ) } \\
\text { 1. It is ethical to use Facebook. (.77) } \\
\text { 2. Facebook is a form of interaction with the society, } \\
\text { community and events. (.60) }\end{array}$ & 3.38 & .88 & 6.80 & 46.15 \\
\hline $\begin{array}{l}\text { Factor } 6 \text { : Openness of Information (Cronback alpha }=.61 \text { ) } \\
\text { 1. I prefer to keep my personal information } \\
\text { only with my friends. (.69) } \\
\text { 2. I prefer to keep my personal information } \\
\text { only with my relatives. (.68) }\end{array}$ & 3.67 & .95 & 6.68 & 52.84 \\
\hline
\end{tabular}

Number in the parenthesis represents the factor loading for each item.

Roy's Largest Root, with the $\mathrm{p}$ value less than .01. The findings suggested that in general demographic variables affected the perceptions toward usefulness, usage, reliability, making new friends, ethic, and openness of information.

\subsection{ANOVA Result and Hypothesis Testing}

To test the hypotheses, ANOVA was run against all six factors with demographic variables (gender, income, marital status, and education). For gender variable, the result showed 
that male and female were different only in the openness of the information factor $(\mathrm{F}=$ $9.808, \mathrm{p}<.01)$. Females agreed more on keeping their information only for their relative and friends, while males were more opened on this issue. Income variable showed the effects on the factors of usefulness $(\mathrm{F}=13.431, \mathrm{p}<.01)$, usage $(\mathrm{F}=3.346, \mathrm{p}<.05)$, reliability $(\mathrm{F}=8.699$, $\mathrm{P}<.01)$, making new friends $(\mathrm{F}=7.022, \mathrm{p}<$ $.01)$, and ethic $(F=3.073, p<.05)$. High-income people had the highest means on usage, reliability and making new friends. Low-income people had the highest means on usefulness and ethic, while middle-income people had all the means in the median range for all six factors. Marital status had impacts on only the factors of usefulness $(\mathrm{F}=3.77, \mathrm{p}<.05)$, reliability $(\mathrm{F}=6.485, \mathrm{p}<.01)$ and ethic $(\mathrm{F}=2.661$, $\mathrm{p}<.10)$. Married people perceived low mean scores on the issues of usefulness, reliability and ethic. For the last hypothesis, the result shows that educational variable had no impact for all the factors. People with different educational levels perceived the same on the six factors. Tables 3, 4, 5, and 6showed comparison of factors on all variables studied. Tables 7,8 ,

〈Table 3〉 Comparison of factors on gender variable

\begin{tabular}{lcccc}
\hline \multirow{2}{*}{ Factors } & \multicolumn{2}{c}{ Male } & \multicolumn{2}{c}{ Female } \\
\cline { 2 - 5 } & Mean & Std & Mean & Std \\
\hline Usefulness & 3.45 & .75 & 3.61 & .79 \\
\hline Usage & 3.23 & 1.03 & 3.02 & 1.03 \\
\hline Reliability & 2.81 & .97 & 2.87 & .95 \\
\hline Making New Friends & 3.46 & .87 & 3.49 & .80 \\
\hline Ethic & 3.38 & .91 & 3.39 & .85 \\
\hline Openness of Information & 3.48 & .95 & 3.91 & .91 \\
\hline Note:
\end{tabular}

Note: 5indicates strongly agree and 1 indicates strongly disagree on the likert scale.

$\langle$ Table 4〉 Comparison of factors on income variable

\begin{tabular}{lcccccc}
\hline \multirow{2}{*}{ Factors } & \multicolumn{2}{c}{$>30,000$} & Dhs & \multicolumn{2}{c}{$10,000-30,000$} & \multicolumn{2}{c}{$<10,000$ Dhs } \\
\cline { 2 - 7 } & Mean & Std & Mean & Std & Mean & Std \\
\hline Usefulness & 3.53 & .65 & 3.24 & .67 & 3.89 & .84 \\
\hline Usage & 3.31 & 1.00 & 2.90 & 1.00 & 3.28 & 1.05 \\
\hline Reliability & 3.14 & 1.06 & 2.50 & .79 & 3.03 & .96 \\
\hline Making New Friends & 3.77 & .65 & 3.22 & .82 & 3.57 & .91 \\
\hline Ethic & 3.51 & .85 & 3.19 & .86 & 3.53 & .91 \\
\hline Openness of Information & 3.85 & 1.03 & 3.51 & .92 & 3.75 & .92 \\
\hline
\end{tabular}

Note: 5 indicates strongly agree and 1 indicates strongly disagree on the likert scale. 
〈Table 5〉 Comparison of factors on marital status variable

\begin{tabular}{lcccc}
\hline \multirow{2}{*}{ Factors } & \multicolumn{2}{c}{ Married } & \multicolumn{2}{c}{ Not married } \\
\cline { 2 - 5 } & Mean & Std & Mean & Std \\
\hline Usefulness & 3.34 & .64 & 3.65 & .83 \\
\hline Usage & 3.01 & 1.01 & 3.22 & 1.04 \\
\hline Reliability & 2.54 & .88 & 3.05 & .96 \\
\hline Making New Friends & 3.41 & .82 & 3.52 & .85 \\
\hline Ethic & 3.21 & .85 & 3.50 & .89 \\
\hline Openness of Information & 3.53 & .99 & 3.78 & .92 \\
\hline
\end{tabular}

Note: 5indicates strongly agree and 1 indicates strongly disagree on the likert scale.

〈Table 6〉 Comparison of factors on education variable

\begin{tabular}{lcccccc}
\hline \multirow{2}{*}{ Factors } & \multicolumn{2}{c}{ High School } & \multicolumn{2}{c}{ Undergraduate } & \multicolumn{2}{c}{ Graduate } \\
\cline { 2 - 7 } & Mean & Std & Mean & Std & Mean & Std \\
\hline Usefulness & 3.45 & .78 & 3.57 & .78 & 3.45 & .69 \\
\hline Usage & 2.93 & 1.01 & 3.18 & 1.03 & 3.42 & 1.02 \\
\hline Reliability & 2.86 & 1.03 & 2.76 & .91 & 3.21 & 1.01 \\
\hline Making New Friends & 3.33 & .84 & 3.53 & .86 & 3.61 & .68 \\
\hline Ethic & 3.48 & .86 & 3.30 & .91 & 3.57 & .76 \\
\hline Openness of Information & 3.52 & .95 & 3.70 & .97 & 3.94 & .84 \\
\hline
\end{tabular}

Note: 5 indicates strongly agree and 1 indicates strongly disagree on the likert scale.

〈Table 7〉 ANOVA results on gender variable

\begin{tabular}{|c|c|c|c|c|c|c|}
\hline Factors & Groups & $\begin{array}{l}\text { Sum of } \\
\text { Square }\end{array}$ & Df & $\begin{array}{l}\text { Mean } \\
\text { Square }\end{array}$ & F & Sig \\
\hline 1. Usefulness & $\begin{array}{l}\text { Between Groups } \\
\text { Within Groups } \\
\text { Total }\end{array}$ & $\begin{array}{r}1.145 \\
108.360 \\
109.505\end{array}$ & $\begin{array}{r}1 \\
181 \\
182\end{array}$ & $\begin{array}{r}1.145 \\
.599\end{array}$ & 1.912 & .168 \\
\hline 2. Usage & $\begin{array}{l}\text { Between Groups } \\
\text { Within Groups } \\
\text { Total }\end{array}$ & $\begin{array}{r}1.999 \\
192.899 \\
194.897\end{array}$ & $\begin{array}{r}1 \\
181 \\
182\end{array}$ & $\begin{array}{l}1.999 \\
1.066\end{array}$ & 1.875 & .173 \\
\hline 3. Reliability & $\begin{array}{l}\text { Between Groups } \\
\text { Within Groups } \\
\text { Total }\end{array}$ & $\begin{array}{r}.157 \\
168.464 \\
168.621\end{array}$ & $\begin{array}{r}1 \\
181 \\
182\end{array}$ & $\begin{array}{l}.157 \\
.931\end{array}$ & .169 & .682 \\
\hline 4. Making new friends & $\begin{array}{l}\text { Between Groups } \\
\text { Within Groups } \\
\text { Total }\end{array}$ & $\begin{array}{r}.045 \\
129.416 \\
129.461\end{array}$ & $\begin{array}{r}1 \\
181 \\
182\end{array}$ & $\begin{array}{l}.045 \\
.715\end{array}$ & .062 & .803 \\
\hline 5. Ethic & $\begin{array}{l}\text { Between Groups } \\
\text { Within Groups } \\
\text { Total }\end{array}$ & $\begin{array}{r}.014 \\
143.440 \\
143.454\end{array}$ & $\begin{array}{r}1 \\
181 \\
182\end{array}$ & $\begin{array}{l}.014 \\
.792\end{array}$ & .018 & .894 \\
\hline $\begin{array}{l}\text { 6. Openess of } \\
\text { information }\end{array}$ & $\begin{array}{l}\text { Between Groups } \\
\text { Within Groups } \\
\text { Total }\end{array}$ & $\begin{array}{r}8.609 \\
158.870 \\
167.478\end{array}$ & $\begin{array}{r}1 \\
181 \\
182\end{array}$ & $\begin{array}{r}8.609 \\
.878\end{array}$ & 9.808 & $.002^{* * *}$ \\
\hline
\end{tabular}

Note: $* * *$ significant at $\mathrm{p}<.01$ 
〈Table 8〉 ANOVA results on income variable

\begin{tabular}{llrrrrr}
\hline \multicolumn{1}{c}{ Factors } & \multicolumn{1}{c}{ Groups } & $\begin{array}{c}\text { Sum of } \\
\text { Square }\end{array}$ & Df & $\begin{array}{c}\text { Mean } \\
\text { Square }\end{array}$ & F & Sig \\
& Between Groups & 14.220 & 2 & 7.110 & 13.431 & $.000^{* * *}$ \\
& Within Groups & 1.934 & 180 & .529 & & \\
& Total & 12.286 & 182 & & & \\
& Between Groups & 6.987 & 2 & 3.493 & 3.346 & $.037^{* *}$ \\
& Within Groups & 187.911 & 180 & 1.044 & & \\
& Total & 194.897 & 182 & & & \\
& Between Groups & 14.861 & 2 & 7.430 & 8.699 & $.000^{* * *}$ \\
& Within Groups & 153.760 & 180 & .854 & & \\
\hline 3. Reliability & Total & 168.621 & 182 & & & \\
& Between Groups & 9.370 & 2 & 4.685 & 7.022 & $.001^{* * *}$ \\
& Within Groups & 120.091 & 180 & .667 & & \\
\hline 4. Making new & Total & 129.461 & 182 & & & $.049^{* *}$ \\
& Between Groups & 4.736 & 2 & 2.368 & 3.073 & \\
\hline 5.Ethic & Within Groups & 138.717 & 180 & .771 & & \\
& Total & 143.454 & 182 & & & \\
\hline 6. Openess of & Between Groups & 3.784 & 2 & 1.892 & 2.080 & .128 \\
information & Within Groups & 163.694 & 180 & .909 & & \\
& Total & 167.478 & 182 & & & \\
\hline
\end{tabular}

Note: ${ }^{* * *}$ significant at $\mathrm{p}<.01,{ }^{* *}$ significant at $\mathrm{p}<.05$

〈Table 9〉 ANOVA results on marital status variable

\begin{tabular}{|c|c|c|c|c|c|c|}
\hline Factors & Groups & $\begin{array}{l}\text { Sum of } \\
\text { Square }\end{array}$ & Df & $\begin{array}{l}\text { Mean } \\
\text { Square }\end{array}$ & $\mathrm{F}$ & Sig \\
\hline 1. Usefulness & $\begin{array}{l}\text { Between Groups } \\
\text { Within Groups } \\
\text { Total }\end{array}$ & $\begin{array}{r}4.403 \\
105.102 \\
109.505 \\
\end{array}$ & $\begin{array}{r}2 \\
180 \\
182\end{array}$ & $\begin{array}{r}2.201 \\
.584\end{array}$ & 3.770 & $.025^{* *}$ \\
\hline 2. Usage & $\begin{array}{l}\text { Between Groups } \\
\text { Within Groups } \\
\text { Total }\end{array}$ & $\begin{array}{r}3.233 \\
191.665 \\
194.897 \\
\end{array}$ & $\begin{array}{r}2 \\
180 \\
182 \\
\end{array}$ & $\begin{array}{l}1.616 \\
1.065\end{array}$ & 1.518 & .222 \\
\hline 3. Reliability & $\begin{array}{l}\text { Between Groups } \\
\text { Within Groups } \\
\text { Total }\end{array}$ & $\begin{array}{r}11.334 \\
157.287 \\
168.621 \\
\end{array}$ & $\begin{array}{r}2 \\
180 \\
182 \\
\end{array}$ & $\begin{array}{r}5.667 \\
.874\end{array}$ & 6.485 & $.002^{* * *}$ \\
\hline 4. Making new friends & $\begin{array}{l}\text { Between Groups } \\
\text { Within Groups } \\
\text { Total }\end{array}$ & $\begin{array}{r}.784 \\
128.677 \\
129.461 \\
\end{array}$ & $\begin{array}{r}2 \\
180 \\
182 \\
\end{array}$ & $\begin{array}{l}.392 \\
.715\end{array}$ & .548 & .579 \\
\hline 5. Ethic & $\begin{array}{l}\text { Between Groups } \\
\text { Within Groups } \\
\text { Total }\end{array}$ & $\begin{array}{r}4.119 \\
139.334 \\
143.454 \\
\end{array}$ & $\begin{array}{r}2 \\
180 \\
182 \\
\end{array}$ & $\begin{array}{r}2.060 \\
.774\end{array}$ & 2.661 & $.073^{*}$ \\
\hline $\begin{array}{l}\text { 6. Openess of } \\
\text { information }\end{array}$ & $\begin{array}{l}\text { Between Groups } \\
\text { Within Groups } \\
\text { Total }\end{array}$ & $\begin{array}{r}2.723 \\
164.755 \\
167.478 \\
\end{array}$ & $\begin{array}{r}2 \\
180 \\
182 \\
\end{array}$ & $\begin{array}{r}1.361 \\
.915\end{array}$ & 1.487 & .229 \\
\hline
\end{tabular}

Note: ${ }^{* * *}$ significant at $\mathrm{p}<.01,{ }^{* *}$ significant at $\mathrm{p}<.05,{ }^{*}$ significant at $\mathrm{p}<.10$ 
〈Table 10〉 ANOVA results on education variable

\begin{tabular}{llrrrrr}
\hline \multicolumn{1}{c}{ Factors } & \multicolumn{1}{c}{ Groups } & $\begin{array}{r}\text { Sum of } \\
\text { Square }\end{array}$ & Df & $\begin{array}{c}\text { Mean } \\
\text { Square }\end{array}$ & F & Sig \\
\hline 1. Usefulness & Between Groups & .639 & 2 & .302 & .529 & .590 \\
& Within Groups & 108.865 & 180 & .605 & & \\
& Total & 109.505 & 182 & & & \\
\hline 2. Usage & Between Groups & 4.051 & 2 & 2.026 & 1.910 & .151 \\
& Within Groups & 190.846 & 180 & 1.060 & & \\
& Total & 194.897 & 182 & & & \\
\hline 3. Reliability & Between Groups & 3.182 & 2 & 1.591 & 1.731 & .180 \\
& Within Groups & 165.439 & 180 & .516 & & \\
& Total & 168.621 & 182 & & & \\
\hline 4. Making new friends & Between Groups & 1.781 & 2 & .891 & 1.256 & .287 \\
& Within Groups & 127.680 & 180 & .709 & & \\
& Total & 129.461 & 182 & & & \\
\hline 5. Ethic & Between Groups & 1.850 & 2 & .925 & 1.176 & .311 \\
& Within Groups & 141.604 & 180 & .787 & & \\
& Total & 143.454 & 182 & & & \\
\hline 6. Openess of & Between Groups & 2.675 & 2 & 1.337 & 1.461 & .235 \\
information & Within Groups & 164.803 & 180 & .916 & & \\
& Total & 167.478 & 182 & & & \\
\hline
\end{tabular}

9, and 10 showed the results of ANOVA.

\section{Discussion and Conclusion}

This study attempted to identify the possible motives for the use of social network site (SNS) among the U.A.E. The results showed that people were motivated to use Facebook because of usefulness, usage and making new friends.

Previous studies found that people used the SNS for many benefits such as making friends, connecting to people, communication, and sharing photos and videos. Other studies also in- dicated that people used the SNS for social purpose such as social searching and browsing. This study found that the motives for using the SNS among the U.A.E people were similar to those found in the previous studies. The results showed that usefulness, usage and making new friends were the form of the benefits that people received from using Facebook. In other words, people were motivated to use the site because of these benefits.

This paper has identified the factors that were not found in other previous studies. These factors were reliability, ethic issue, and openness of information. These factors were considered as an obstable from using the Facebook. In 
other words, people were not motive to use the site because of reliability, ethic issue, and openness of information. From the interview, people were concerned about the reliability of the site. They were worried about the information they shared on the web including their privacy. Safety and security from using the site were also mentioned from the respondents, and they were found as an important factor that affected the use of the site.

One of the unique finding in this paper was that ethical issue was one of the major concern when people accessed to the site. This may due to the cultural aspect. Whether using the Facebook or other SNS is appropriate in this cultural environment is one of the major issues in the society. From the interview, the study revealed that people were reluctant to use the SNS because it was not appropriate.

Openess of information was one of the factors found in this study. The results showed that people preferred to keep their personal information for their friends and relatives. Sharing information to outsiders was limited. Privacy and safety issue were major parts that limit the use of the site. From the interview, people preferred to share the minimum information as much as they could. Majority of the people limited their activities such as showing photo when they appeared online at the site.

Many previous studies examined only the effect of gender and education but not the effect of other variables such as income and married status. This study made contribution by examining other variables such as income and married status. These findings helped us to understand how the demographic variables affected the use of the SNS among people in UAE.

For the income variable, people with low income perceived the usefulness the greatest compared to higher income, while gender and educational variables were not significant factors for the usefulness. However, there was different perception toward the ethical issue. People with middle-income class agreed less on the ethical issue compared with other groups. They felt that it was not appropriate to use Facebook, and they agreed less on the issue that Facbook was the form for the interaction with the society.

An interesting finding for this paper was that married people and non-married people perceived differently on the reliability issues. Married people had a very low mean score on the reliability compared to non-married group. Married people believed that the site was not secure and safe and it was no privacy when using the site. Another interesting finding for the gender variable was that women agreed less on the openness of information compared to men. Women preferred to keep their personal information only for their relatives and friends. This finding supported previous studies that women were more likely not to reveal their information to the public. 


\section{Limitation and Future Research}

The first limitation in this study was that the survey was done on a non-random sampling, so the results had a limitation on the generalization to the U.A.E. population. Conducting future research using diverse groups or random sampling method may be needed.

Qualitative method may be needed to explore the knowledge about how the demographic variables will affect the use of SNS in this culture. Dept interviews will provide more value information about this issue.

Lastly, U.A.E. is one of the countries in Middle East, and it is also a member of GDC countries. Whether people from other GDC countries such as Saudi Arabia or Qatar will have the same perception toward the use of social network such as Facebook will be an interesting for research. The findings will be useful for an implication in marketing and management areas focusing on GDC countries.

〈Received May 28. 2013〉

$\langle 1$ st Revised February 17. 2014〉

〈2nd Revised February 24. 2014〉

〈Accepted February 27. 2014〉

\section{References}

Barkhuus, L. and Tashiro, J. (2010). Student socialization in the age of Facebook. Or- ganizations and Communities (pp. 133-142), Atlanta, G.A.

Bimber, B. (2000). The gender gap on the internet. Social Science Quarterly, 81(3), 868-876.

Boyd, D. (2008). Why youth (heart) social network sites, the role of networked publics in teenage social life. In D. Buckingham (Ed), Youth, Identity, and Digital Media (pp. 119-1442). Cambridge, MA, MT Press.

Cheung, C., Chiu, P. and Lee, M. (2011). Online social networks: Why do students use Facebook?. Computers in Human Behavior, Vol. 27, (pp. 1337-1343).

DiMaggio, P., Hargittai, E., Celeste, C., \& Shafer, S. (2004). Digital equality: From unequal access to differentiated use. In $\mathrm{K}$. Neckerman (Eds.), Social Inequality, (pp. 355-400). New York: Russell Sage Foundation.

Donath, J. \& Boyd, D. (2004). Public displays of connection. BT Technology Journal, 2 (4), 71-82.

Gross, R. \& Acquisti, A. (2005). Information revelation and privacy in online social networks (The Facebook Case). Proceedings of ACM Workshop on Privacy in the Electronic Society. Alexandria, VA: Association for Computing Machinary, 71-80.

Hair, J. F., Anderson, R.E., Tatham, R. L., \& Black, W.C. (1998). Multivariate Data Analysis ( $5^{\text {th }}$ ed.). Upper Saddle River, NJ: PrenticeHall.

Hargittai, E. \& Shafer, S. (2006). Differences 
in actual and perceived online skills: The role of gender. Social Science Quarterly, 87 (2), 432-448.

Hargittai, E. (2008). Whose space? Differences among users and non-users of social network sites. Journal of Computer-Mediated Communication, 13(1), 276-297.

Hodge, M. J. (2006). The fourth amendment and privacy issues on the "New" internet Facebook.com and MySpace.com. Southern Illinois University Law Journal, 31, 95-123.

Howard, P. N., Rainie, L. \& Jones, S. (2001). Days and nights on the Internet: The impact of a diffusing technology. American Behavioral Scientist, 45(3), 383-404.

Jackson, Linda .A., Ervin, Kelly S., Gardner, Phillip D., \& Schmitt, Neal. (2001).Gender and the internet: Women communicating and men searching. Sex Roles, 44 (5/6), 363-379.

Joinson, A. N. (2008).Looking at, looking up, or keeping up with people? Motives and uses of Facebook. Proceeding paper at Online Social Networks, Florence, Italy.

Lenhart, A. \& Madden, M. (2007).Social networking websites and teens: An overview. Pew Internet and American Life Project Report. Retrieved from//www.pewinternet. org/PDF/r/198/report_display.asp

Lin, Trisha T.C., Chiu, Vicki C.H., \& Lim W. (2011). Factors affecting the adoption of social setwork sites: Examing four adopter categories of Singapore's working adults.
Asian Journal of Communication, 21(3), 221-242.

Livingstone, S. \& Helsper, E. (2007). Gradations in digital inclusion: Children, young people, and the digital divide. New Media and Society, 9, 671-696.

Madden, M. \& Raine, L. (2003). American Online Pursuits. Pew Internet and American Life Project Report. Retrieved from http: //www.Pewinternet.org/PDF/r/182/report _display.asp? $\mathrm{r}=106$

Mansumitrchai, S., Park, C. and Chiu C. (2012). Factors underlying the adoption of social network: A study of Facebook users in South Korea. International Journal of Business and Management, 7(24), 138-153.

Mossberger, K., Tolbert, C. J., \& Stansbury, M. (2003). Virtual inequality: Beyond the digital divide. Washington, D.C.: Georgetown University Press.

Ono, H. \& Zavodny, M. (2003). Gender and the internet. Social Science Quarterly, 84 (1), 111-121.

Sheldon, P. (2008). Student favorite: Facebook and motives for its use. Southwestern Mass Communication Journal, 23(2), 39-53.

Sheldon, P. (2012). Profiling the non-users: Examination of life-position indicators, sensation seeking; shyness, and loneliness among users and non-users of social network sites. Computers in Human Behavior, 28, 1960-1965.

Stafford, R. (2006). Why prentsmstmnd My 
Space. Retrieved from http://www/msnbc. msn.com/id/11064451/

Tufekci, Z. (2008). Can You See Me Now? Audience and Disclosure Regulation in Online Social Network Sites. Bulletin of
Science, Technology and Society, 28 (1), 20-36.

Van Dijk, J.A.G.M. (2005). The deepening divide. London: Sage Publications. 